\title{
SPECTRUM OF NEUROLOGICAL MANIFESTATIONS IN COVID-19: A REVIEW
}

\author{
FIROZ AHMED QURAISHI ${ }^{1}$, AMINUR RAHMAN $^{2}$, FURIAL QURAISHI TWINKLE $^{3}$
}

\begin{abstract}
:
The COVID-19 pandemic, caused by severe acute respiratory syndrome coronavirus 2 (SARS-CoV2) is causing a worldwide pandemic of COVID-19 within a short span of time. Although patients with COVID-19 primarily present with fever and respiratory illness; a wide range of symptoms involving different systems have been described. While the neurological sequelae of the virus remain poorly understood, there are a growing number of reports of neurological manifestation of COVID-19.The neurological manifestation including both central and peripheral nervous system are increasingly reported in a very subset of COVID-19 patients. The SARS-CoV-2 enters the body mainly via the ACE2 receptors within the respiratory system, which causes the body to initiate an immunologic response against potential damage to non-renewable cells. There's increasing evidence of accumulating that COVID-19, particularly in severe cases, can have neurological consequences although respiratory symptoms nearly always develop before neurological ones. Patients with pre-existing neurological conditions could also be at elevated risk for COVID-19 associated neurological symptoms. The neurological presentations of COVID-19 patients maybe acute and post-acute state. The acute presentations are classified into specific (such as stroke, encephalitis, acute polyneuropathy, etc.) and nonspecific (such as delirium, headache, dizziness, etc.) symptoms with anatomical involvement of either central nervous system including brain or spinal cord, and/or peripheral nervous system, neuromuscular junctions or muscles. Several neurological symptoms have also been demonstrated in post-acute or long covid-19 syndrome. There is a possibility to overlook or misinterpretation of, neurological symptoms in some COVID-19 patients. In infants and young children, the foremost common CNS phenomena are febrile seizures; in adults, non-focal abnormalities will be either neurological or constitutional. To date, neurological manifestations of COVID-19 are described largely within the disease trajectory, and also the long-term effects of such manifestations still remain unexplored and unfolded. This article is intended to review the possible neuro-invasive routes of SARS-CoV-2 and its mechanisms which initiate the neurological damage with neurological presentations of COVID-19 patients.
\end{abstract}

Key words: Spectrum, Neurological Manifestations, COVID-19

Received: 16.5.2021

Accepted: 28.5 .2021

DOI: https://doi.org/10.3329/bjm.v32i2.53790

Citation: Quraishi FA, Rahman A, Twinkle FQ. Spectrum of Neurological Manifestations in COVID19: A Review. Bangladesh J Medicine 2021; 32: 120-137.

\section{Introduction:}

Coronavirus disease 2019 (COVID-19) is a communicable disease caused by SARS-CoV-2.The primary known case was identified in Wuhan, China, in December $2019^{1}$. The disease has since spread worldwide, resulting in an ongoing historical pandemic ${ }^{2}$. Transmission of COVID-19 occurs mainly when an infected person is in close contact with another person ${ }^{3.4}$. Small droplets containing the virus can spread from an infected person's nose and mouth as they breathe, cough, sneeze, sing, or speak. People are infected if the virus gets into their mouth, nose, or eyes. The transmission mechanism is additionally sometimes possible, as smaller infected droplets and particles can linger within the air for minutes to hours within enclosed spaces that have inadequate ventilation ${ }^{4}$. Less commonly, the virus may spread via contaminated surfaces ${ }^{4}$. People who are infected can transmit the virus to other person up to two days before they themselves show symptoms, as can people who

1. Professor of Neurology, Anwer Khan Modern Medical College and Hospital, Dhaka-1100, Bangladesh.

2. Assistant Professor, Dept of Neurology, Sir Salimullah Medical College, Dhaka-1100, Bangladesh.

3. Final Year Medical Student, Anwer Khan Modern Medical College and Hospital, Dhaka-1100, Bangladesh. Address of Correspondence: Professor Dr. Firoz Ahmed Quraishi. Email: firoz148@yahoo.com; Cell phone: 8801819244149 
do not experience symptoms ${ }^{5.6}$. People remain infectious for up to 10 days after the onset of symptoms in moderate cases and up to twenty days in severe cases $^{6}$. The morbidity and the mortality rate associated with covid-19 varies among different countries, which can be attributed in part to the median age of the affected population and the availability of critical resources needed to diagnose and treat the patients ${ }^{7}$ . The clinical manifestation of the covid-19 are highly variable with $45 \%$ of the covid- 19 positive cases being asymptomatic ${ }^{8}$.The most common observed symptoms of covid-19 were fever, cough and fatigue and most common co-morbidities identified were hypertension and diabetes mellitus ${ }^{9}$.In a prospective cohort study by Cummings and colleges with confirmed covid-19 cases $22 \%$ were critically and $67 \%$ of the critically ill patients were men. The most common reported symptoms were shortness of breath $74 \%$, fever $71 \%$, and cough $66 \%$, myalgia $26 \% .39 \%$ of these patients died 10122 . According to many reports and studies SARS-CoV2 virus that causes covid-19 is associated with diverse neurological tropism with complications. These complications can involve either central nervous system, peripheral nervous system, neuromuscular junctions and muscles. These manifestations could be nonspecific such as headache, delirium, myalgia or more specific disease or syndromes (such as stroke, encephalitis, seizures, peripheral neuropathy) which require immediate medical attention. ${ }^{11} .12$. So the aim of the present study is to review the possible mechanisms of SARS-CoV-2 neuro-pathogenesis together with the most important neurological manifestations reported in patients with COVID-19.

\section{Epidemiology:}

Based on Johns Hopkins University statistics, the worldwide death-to-case ratio of SARS-CoV-2 is 2.1 percent $(3,237,808$ deaths for $154,788,122$ cases) as of 6 May 2021 13. Two large cohort-based studies on neurological manifestations of COVID-19 are reported thus far. During a study that wiped out Wuhan, Mao and colleagues from China noted that among 214 severely affected patients, $78(36.4 \%)$ had neurological complications. CNS involvement was noted in 53 (24.8\%) patients. In total, 19 (8.9\%) patients had peripheral nervous system involvement. Rest, 23 (10.7\%) had skeletal muscle injury ${ }^{11}$. Another study conducted in France, by Helms and associates recorded neurological manifestations in 58 severely ill patients. The median age of those patients was 63 years ${ }^{14}$. Agitation was the foremost frequent neurological complication (69\%; 40/ 58) 15 . The differences in percentage between the 2 studies could also be because the second study focused on more severely affected COVID-19 patients.

\section{Pathophysiology and Pathology:}

The pathophysiology of covid-19 is diverse. It can be categorized as follows:

\section{Direct viral injury-}

Mechanism of CNS damage associated with SARS-CoV2 like other well recognized neuro invasive human viruses may invade CNS via trans-synaptic propagation through the olfactory epithelium or through systemic circulation entering the CNS using endothelial ACE-2 receptors expressed in cerebral blood vessels, or crossing the disrupted blood brain barrier (BBB) by systematically produced cytokines (Fig.-1).

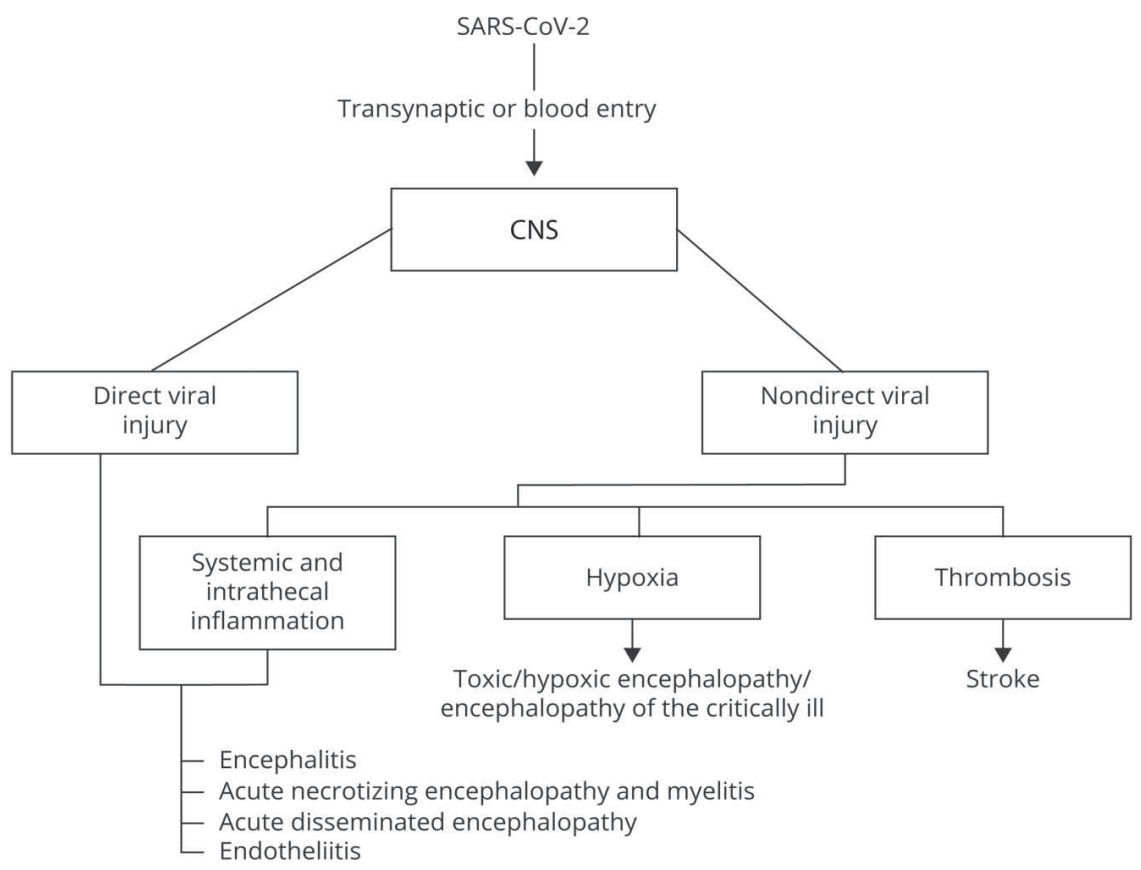

Fig.-1: Proposed CNS entry routes, mechanisms and their respective associated clinical pictures Presentations and mechanisms of CNS disorders related to COVID-19 Marta Bodro, Yaroslau Compta, Raquel Sánchez-Valle, DOI: https://doi.org/10.1212/NXI.0000000000000923 
The SARS-CoV-2 reaches the CNS by different routes and may induce short term illness such as viral encephalitis like or endotheliitis. On the other hand it might persist in resident cells of CNS and be involved in long term neurological sequel in genetically or otherwise predisposed individuals 16 .

Beside this ACE2 receptors are highly concentrated in the substantia nigra and ventricles of the brain and also found in many neurons, astrocytes, oligodendrocytes, middle temporal gyrus and posterior cingulate cortex ${ }^{17}$. (Fig.-2)

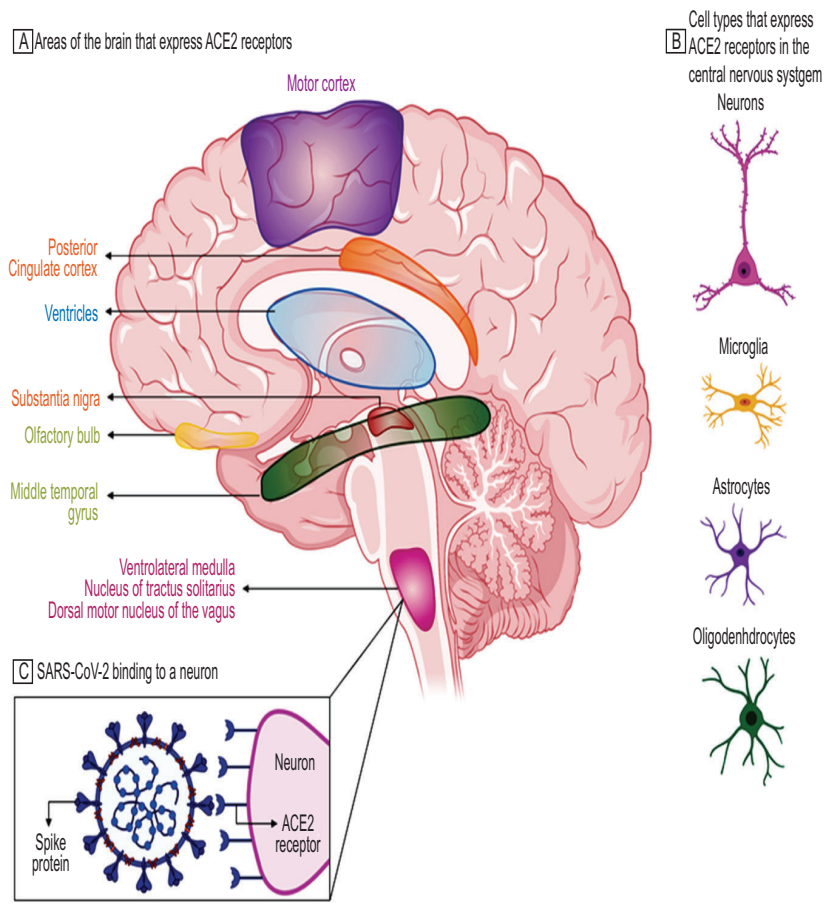

Fig.-2: Emerging data suggest that ACE2 receptors are expressed in multiple regions of the human and mouse brain, including the motor cortex, posterior cingulate cortex, ventricles, substantia nigra, olfactory bulb, middle temporal gyrus, ventrolateral medulla, nucleus of tractus solitarius, and dorsal motor nucleus of the vagus nerve (A) and on several key cell types that make up the central nervous system, including neurons, microglia, astrocytes, and oligodendrocytes (B).35-37 C, $A C E 2$ receptors on a medullary neuron binding to the SPIKE protein on severe acute respiratory syndrome coronavirus 2 (SARS-CoV-2). [Ref: Zubair AS, et al. JAMA Neurol. 2020;77(8):1018-1027]

\section{Neuronal pathway:}

Handful of Human corona viruses such as HCOOC43,HCOV-229E, and SARS-CoV1 can be considered neurotropic viruses due to their capacity to invade the CNS via neuronal pathway. 16, 18
Viruses can migrate by infecting sensory or motor nerve endings, achieving retrograde or anterograde neuronal transport through kinesins, dynein, and motor proteins. 19

In a study by Ding et al ${ }^{14}$ SARS-CoV-1 virus was detected exclusively in the neurons of the brain. The SARS-CoV-1 virus has also been found in the CSF. A transgenic-mouse study found SARS-CoV-1 entry into the brain via the olfactory bulb ${ }^{15}$ and a similar pathway has been postulated in humans. The entry of SARSCoV-2 to the olfactory bulb through the cribriform plate might explain smell impairment in COVID-19.SARSCoV-2 could cause respiratory failure through affecting the brain stem as other coronaviruses have been found to invade the CNS.

\section{Blood circulation pathway:}

Viruses can enter the CNS without infecting neurons. Some viruses such as HIV infect leucocytes and may infiltrate the brain parenchyma. This Trojan horse mechanism is facilitated by the fact that the infected cells are naturally able to cross the blood brain barrier. 20

Alternatively other viruses such as Japanese encephalitis virus are released in to the blood and increase the permeability of blood brain barrier through increased production of pro inflammatory cytokines that facilitates entry into the CNS. ${ }^{21}$

Inflammatory-mediated Injury and cytokine storm in brain: (Fig.-3)

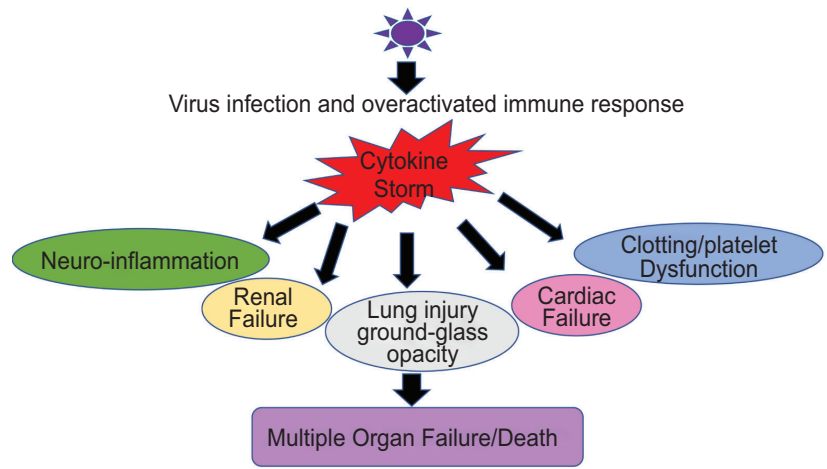

Fig.-3: Multiple Organ Failure because of "Cytokine Storm." The cartoon representation of how "Cytokine Storm" generated during respiratory viral infections can damage not only its primary infection site (i.e., lungs) but also disrupt the homeostasis at the kidneys, heart, intestine, cerebral parenchyma, and blood vessels because of the ubiquitous presence of ACE2 receptors. In severe cases, this leads to Multiple Organ Failure and the eventual death of patients.

https://doi.org/ 10.3389/fimmu.2020.565521 
Cytokine storm could be a condition where the regulators of inflammatory immune responses, and thereby the production of cytokines, becomes out of proportion and out of place. This leads to the assembly of an uncontrolled amount of inflammatory molecules. Cytokine storm happens in multiple bacterial and viral infections and septic conditions, however, the term "Cytokine storm" only gained its popularity after being discussed within the context of Influenza disease in $2005^{22}$.

This overreacting innate immunologic response creates matters of "Cytokine Storm" which generally implies that pro-inflammatory and anti-inflammatory cytokine levels are high within the serum of patients. These cytokine flares are usually destructive for all vital organs like the heart, kidneys, and lungs (Figure: 3). If such a scenario happens within the brain, this becomes extremely devastating and further paves the way for meningitis, encephalitis, meningoencephalitis, and overall neurodegenerative conditions ${ }^{23}$.

\section{Endotheliitis:}

The binding of SARS-CoV-2 to the ACE-2 receptor may cause or worsen high blood pressure, increase the risk of cerebral hemorrhage. Moreover the interaction of the SARS-CoV-2 with spike protein with ACE-2 receptors expressed in the capillary endothelium of brain blood vessels, may lead to injury of the blood brain barrier. This could explain the increase risk of ischemic stroke accompanied by perivascular inflammation suggestive of endothelitis. 24

\section{Hypoxia Mediated Injury and Encephalopathy} (Fig.-4)

Diffuse alveolar and interstitial inflammatory edema in COVID-19 leads to impairment of alveolar gas exchange and central nervous system hypoxia. Anaerobic metabolism in the mitochondria of the brain cell results in acidosis, vasodilation, increase interstitial edema, obstruction of cerebral blood flow by microthrombus, increased intracranial pressure all contribute to coma and acute confusional state. ${ }^{24}$

This encephalopathy is an independent predictor of mortality and associated with long term cognitive dysfunction. ${ }^{25}$

The mechanisms underlying this encephalopathy are heterogeneous and multifactorial. They include: 26

- Direct brain injury

- Respiratory, heart, renal or liver failure ( multi organ dysfunction, Fig.-3)

- Sepsis and septic shock

- Endocrine or electrolyte imbalance

- Effects of pharmacological agents

\section{Non-immunological}

\section{Immunological}

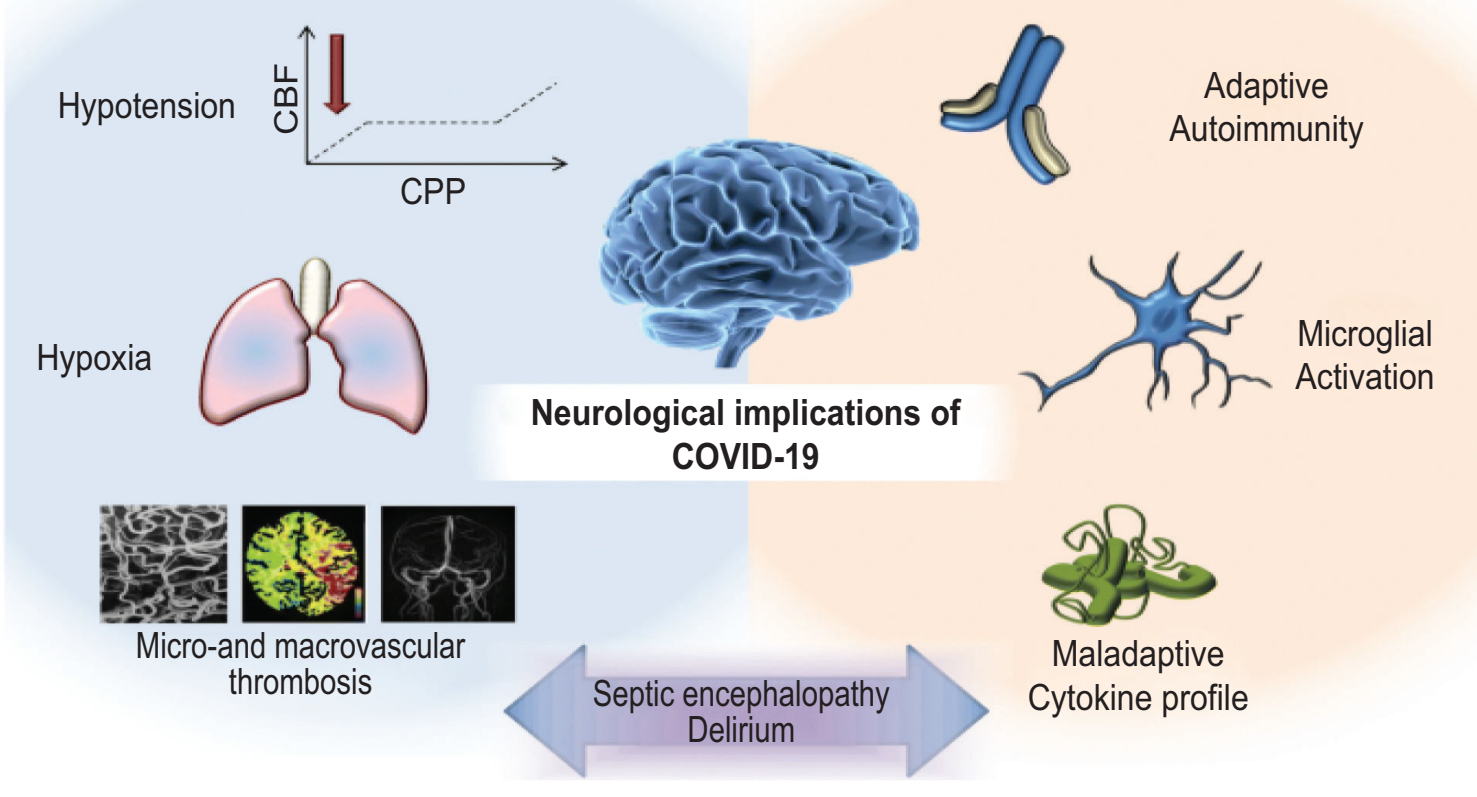

Fig.-4: Putative mechanisms underlying neurological consequences of COVID-19

Edward J Needham ${ }^{1,2}$, Sherry H-Y Chou ${ }^{3}$, Alasdair J Coles, David K Menon 'Neurological Implications of COVID19 Infection,DOI:10.1007/s12028-020-00978-4 


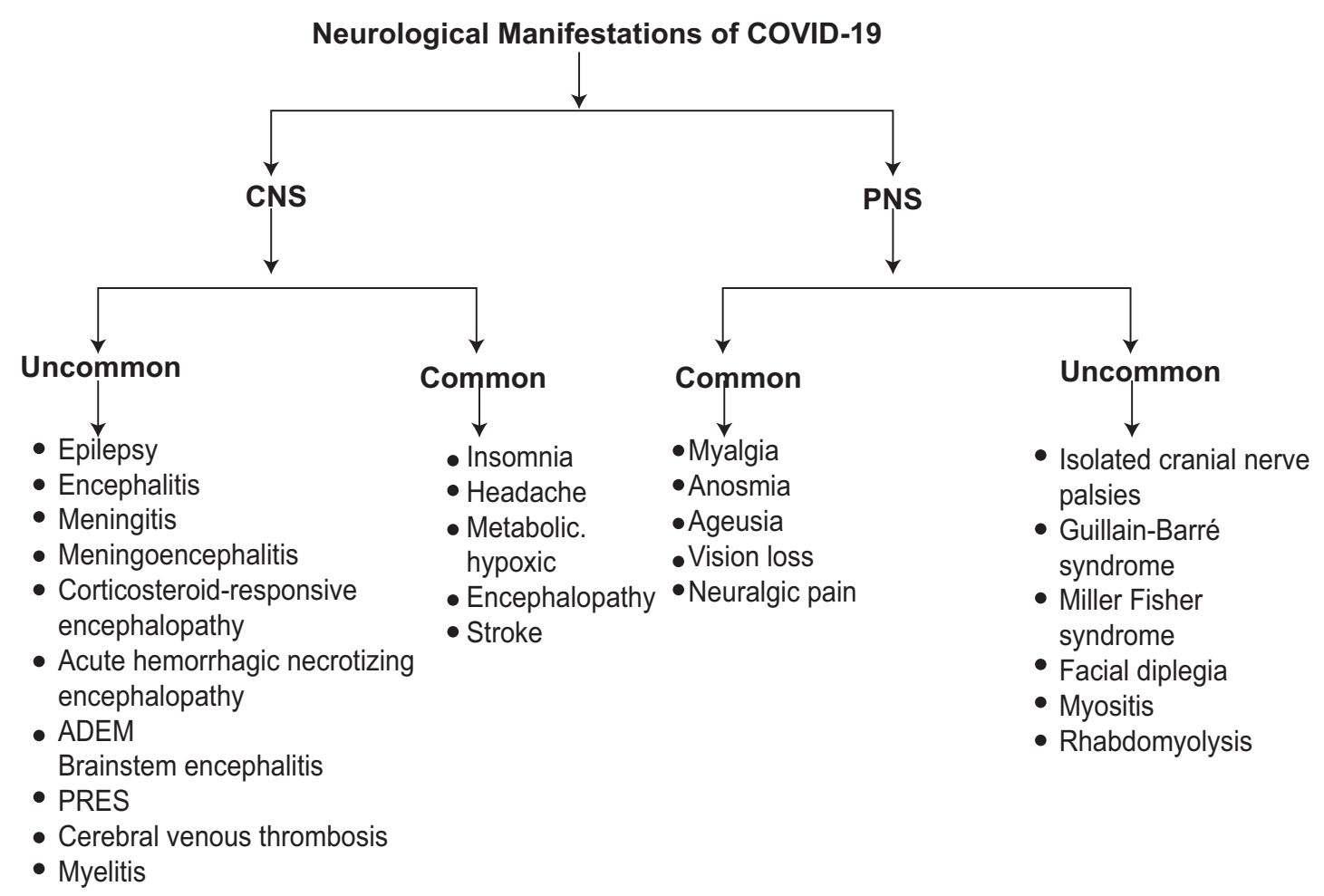

Flowsheet: 1 Neurological manifestations of COVID-19

\section{Neurological manifestations:}

As SARS-CoV-2 presents neurotropic properties, neurological disease manifestations may occur in both symptomatic and asymptomatic patients ${ }^{27}$. In particular, various neurological manifestations have been described in COVID-19 patients, involving the central nervous system, peripheral nervous system, neuromuscular junctions and skeletal muscles. In COVID-19, a variety of neurological complications have been reported. It may be broadly classified in to A) Acute Neurological complications and B) Post-Acute or long COVID-19 complications. The acute complications may be i) Non-specific neurological complications ii) Specific Neurological complications. The neurological complications of COVID-19 are either because of direct viral invasion, cytokine storm, or hypoxic metabolic changes, with the involvement of CNS or peripheral nervous system (PNS) or both ${ }^{11,14}$ as shown in Flowsheet 1.

\section{Nonspecific Neurological complications:}

The incidence of nonspecific neurological complications in patients with confirmed COVID-19 has been reported in several studies. These symptoms include headache, dizziness, delirium, altered mental state, depressed level of consciousness, loss of taste or altered taste sensation, loss of smell, myalgia, and fatigue ${ }^{11}$, 12. The spectrum of nonspecific neurological symptoms ranges from $30-40 \%$.Neurological symptoms are more with severe COVID-19 than moderate and mild forms, with more common involvement of Central nervous system than Peripheral one. A retrospective study by Mao and colleagues demonstrated about $24.8 \%$ experienced CNS symptoms, 8.9\% PNS symptoms (smell, taste, vision),Musculoskeletal symptoms was observed in $10.7 \%$ of patients ${ }^{11}$.

\section{Headache and dizziness:}

In many meta-analyses, headache and dizziness are the foremost common initial neurological manifestations of COVID-19. This two are very common neurological symptoms such as meningitis, encephalitis and vasculitis. They can also occur in temporal association with a systemic viral infection ${ }^{27}$.In these meta-analyses and systematic reviews, the incidence of headache was ranged from $10 \%$ to $15 \%{ }^{28}$, 29. A recent European study had noted a distinct clinical profile of younger (median 37 years) COVID19 patients. In 1,420 mild-to-moderate COVID-19 patients, headache $(70 \%)$ was the foremost prevalent symptom. Wang and colleagues reported headache as fourth common neurological symptom ${ }^{30}$. Preexisting migraine may worsen due to COVID -19-related stress 31. Belvis during a recent communication opined that COVID-19-associated acute headaches will be due to systemic viral infection, primary cough headache, and tension-type headache. A headache appearing 
between the 7 th and the 10 th days of illness is associated with cytokine storm 32 .

Several potential underlying pathophysiological mechanisms of headache were suggested. Notably, it could be due to a direct invasion of SARS-CoV-2 to the trigeminal nerve endings in the nasal cavity. The other proposed underlying mechanism is trigeminovascular activation due to involvement of the endothelial cells of the vessel walls with high expression of angiotensin-converting enzyme-2(ACE-2). A third proposed mechanism, the release of the proinflammatory mediators and cytokines during COVID19 might stimulate the perivascular trigeminal nerve endings and cause headache. 27,33

\section{Delirium:}

The overall incidence of delirium across the clinical spectrum from mild to severely ill patients in COVID19 in unknown. Delirium can be only presenting symptom of SARS-CoV-2 infection 34,35 even in younger patients ${ }^{107}$ The incidence of delirium in severely ill COVID-19 patients on ICUs is reported to be as high as $84 \%{ }^{36}$. Of which more than $2 / 3^{\text {rd }}$ exhibit hyperactive delirium, despite receiving high sedation and neuroleptics 36.

Delirium in COVID-19 maybe a feature of primary encephalopathy due to the direct intracerebral viral infection ${ }^{37}$. Alternatively secondary encephalopathy may be associated with neuro inflammatory response to SARS-CoV-2 with immune mediated systemic response or independent complications of hypoxemia, sepsis, hypo-perfusion, severe metabolic derangement, and pharmacological side effects. ${ }^{38,39}$

\section{Loss of the sense of taste and smell:}

It is still uncertain whether the taste and smell alterations are due to inflammation of the nasal tract or damage to the sensory neurons within the neural structure. A large number of cells within the nasal epithelium express the angiotensin-converting enzyme2 (ACE-2) receptor which is the cell entry receptor for SARS-CoV-2 ${ }^{40}$. However, Brann et.al noted an absence of ACE-2 receptors within the olfactory sensory neurons and suggested inflammation could also be the first cause for little impairment ${ }^{41}$ ACE- 2 receptors are found to be expressed in olfactory sustentacular cells and other non-neuronal cells within the olfactory epithelium ${ }^{42}$. These cells maintain the integrity of the sensory neurons and damage to those may result in alterations in smell and taste. In an exceedingly study of patients hospitalized in Wuhan, the prevalence of hypogeusia and hyposmia was $5.6 \%$ and $5.1 \%$, respectively, 43 while $19.4 \%$ of patients in Italy had some sort of chemosensory dysfunction 42 . Approximately $88.5 \%$ and $88.0 \%$ of patients in Germany reported olfactory and gustatory dysfunction, respectively ${ }^{44}$. Of patients without nasal congestion,
$79.7 \%$ were hyposmic ${ }^{44}$. Anosmia has also been noted in other respiratory infections, like influenza, ${ }^{45}$. In COVID-19, anosmia is not usually associated with nasal swelling or rhinitis.

A meta-analysis by Wang and colleagues reported 35.7$85.6 \%$ olfactory and 33.3-88.8\% gustatory dysfunctions in patients with COVID-19. ${ }^{46}$ Study by Lechien and colleagues reported $86.6 \%$ olfactory disorder in which $11.8 \%$ of olfactory dysfunction preceded other symptoms. Olfactory dysfunctions were significantly associated with fever. They also reported in another large prospective study that females and younger patients were frequently report loss of smell. 47

An European study of 417 COVID-19 patients, conducted across four counties, found $85.6 \%$ and $88 \%$ to possess impairment of the sense of smell and taste, respectively ${ }^{44}$. At present, there are only some studies on this aspect from the Asia-Pacific region. As an example, Mao et al. ${ }^{18}$ found $5.6 \%$ and $5.1 \%$ of their cohort to possess taste and smell impairment, respectively ${ }^{11}$.

\section{Other nonspecific neurological symptoms:}

Other common nonspecific neurological symptoms were asthenia (63\%), myalgia (63\%), A fewer number of patients reported a reduction in visual sense ( $\mathrm{n}=$ $6)$, vertigo $(n=6)$, and tinnitus $(n=5)$. Fever and cough was reported only by $45 \%$ of patients ${ }^{48}$. It is uncertain whether these two manifestations were caused by an immediate effect of the infection on the system or because of other factors like stress, fear, or anxiety.

\section{Specific Neurological complications: Stroke and Vascular Events:}

The Cerebrovascular disease in COVID-19 is also because of high levels of inflammation and/or a hypercoagulable state. Raised serum interleukin and C-reactive protein concentration are reported, and coagulation abnormalities are increasingly noted with raised D-dimer concentration pointing to a poorer prognosis ${ }^{49}$. $\mathrm{Li}$ and associates, during a retrospective study, noted that found $5 \%$ to own acute ischemic stroke 11 , each of one patient had cerebral venous thrombosis and one with cerebral hemorrhage. The majorities of stroke patients were elderly and were affected by severe COVID-19. Comorbidities were common ${ }^{50 .}$ Beyrouti and associates, in an exceedingly report of six severely affected patients with large cerebral infarcts, noted elevated D-dimer levels (e"1000 ig/L), indicating a coagulopathy ${ }^{51}$. More specific viral mechanisms may additionally increase the risk of stroke.

Infection of the vascular endothelial cells and subsequent damage to vasculature may increase the 
chance of ischemic and hemorrhagic infarcts. Many infections can increase the risk of stroke, often through systemic inflammation, thrombosis, or vasculitis 52 , 53 (Flowsheet 2). Helms et al. ${ }^{14}$ reported two cases of acute cerebral ischemic stroke and one of subacute cerebral ischemia. In a very retrospective cohort-based study from New York, USA, 0.9\% had imaging-proven acute ischemia and most (65\%) strokes were cryptogenic, possibly associated with an acquired hypercoagulability 54 . A recent systematic review showed the incidence of acute Stroke in COVID-19 to be $0.9 \%$ to $2.7 \%$ with a mortality of $38 \% 55$. Covid- 19 associated coagulopathy and vascular endothelial dysfunction were plausible mechanisms ${ }^{56}$. Patients were more likely to have hypertension and hypercoaguble status and stroke indicated a poor prognostic marker. ${ }^{50}{ }^{169}$ In a retrospective analysis of 3218 COVID-19 patients admitted in a tertiary care hospital in New York city, Jain and colleagues demonstrated acute stroke was $1.1 \% .{ }^{57}$ In addition the severity of acute ischemic stroke in Global COVID-19 stroke registry, Ntaios and colleagues found that patients with COVID-19 had higher odds of developing severe illness compared to patients without COVID1958 .In patients with stroke, the SARS-CoV-2 virus couldn't be demonstrated in CSF 59.

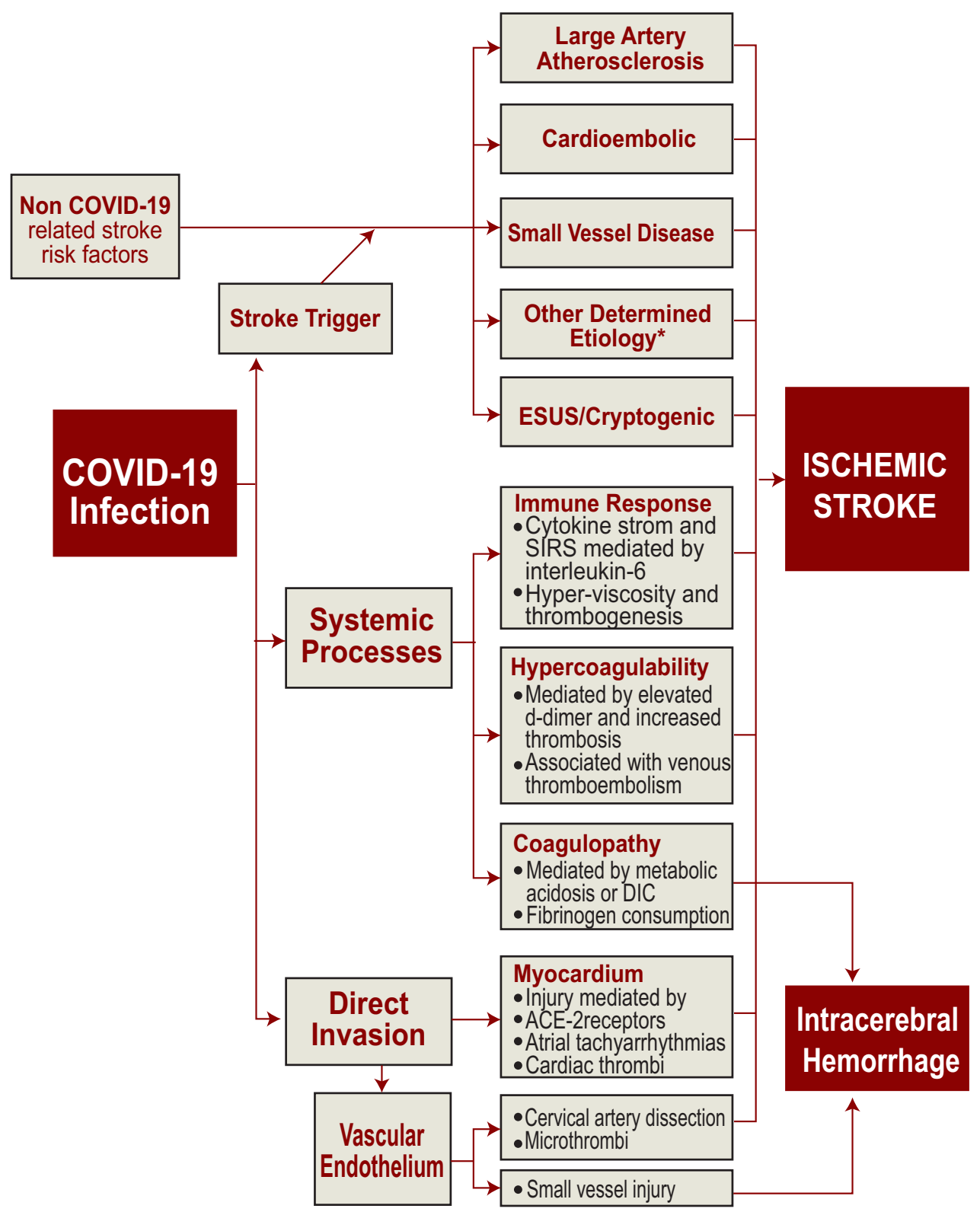

Flowsheet 2: Mechanism of Stroke in COVID-19 
In another study by Shingo and colleagues ${ }^{183}$ observed a significantly greater frequency of large Vessel Occlusion (LVO) strokes in patients with COVID-19 then in patients without COVID-19 ${ }^{60}$. After further control for race and ethnicity in multivariate analysis, patients with COVID-19 had an LVO stroke risk 2.4 times that of patients without COVID-19. Study also highlighted that $62 \%$ of the large vessel strokes involved occlusion of the M1-M2 segments of the middle cerebral artery. 60

\section{Subarachnoid Hemorrhage:}

Cases of acute subarachnoid hemorrhage have been described by Crean and colleagues and Al Saiegh and colleague ${ }^{61}$.

\section{Massive Cerebral Hemorrhage:}

Massive cerebral hemorrhage is defined as those lesions at least $3 \mathrm{~cm}$ in largest dimension in cerebral hemisphere or $1.5 \mathrm{~cm}$ if lesion is in brain stem ${ }^{62}$.A case of massive cerebral hemorrhage in a 38 year old with COVID-19 has been reported 63 .Intracranial hemorrhage was seen in about $0.5 \%$ of the patients with COVID-19 in large population studies $11,{ }^{64}$.In critically ill patients COVID-19 has been associated with coagulopathies such as Disseminated intravascular coagulopathy(DIC), thrombocytopenia, elevated D-dimer, prolonged prothrombin time which can result in hemorrhage 16 . Another potential mechanism is the effect of SARS-CoV-2 on ACE-2 which is the entry and binding site of the virus. ACE2 is also a critical component of the counter regulatory pathway of the Renin Angiotensin System (RAS), which is one of the most important regulators of blood pressure. SARS-CoV-2 induced ACE-2 down regulation may lead to vasoconstriction and cerebral autoregulation dysfunction and subsequently blood pressure spikes which eventually can cause arterial wall rupture and hemorrhage 65 .

\section{Cerebral Venous sinus Thrombosis:}

Cerebral venous sinus thrombosis was reported in 13 patients out of 9 studies ${ }^{27}$. Overall it was shown that venous and arterial thromboembolic complications are seen in 5-15\% of the patients with severe COVID-19 66. Combination of low grade DIC and a localized cerebral thrombotic micro-angiopathy might be the cause 66 . Besides, in patients with COVID-19 a transient rise of antiphospholipid antibodies is seen which may play a role in pathophysiology of thrombosis 66. Cytokine storm which suppresses the anticoagulant pathways and release of von Willebrand factor might lead to venous thrombosis in critically ill COVID-19 patients. 66

\section{Encephalopathy:}

Acute encephalopathy is a nonspecific term defined as the acute impairment of brain function present clinically as alteration of level of consciousness ${ }^{67}$. It is mostly triggered by infections, especially those caused by viruses ${ }^{68}$. Encephalopathy may also present at the early stage of the disease or as a disease initial symptom. Many forms of COVID-19 associated encephalopathy has been documented as clinical features of SARS CoV-2 infections 69 .A study by Scullen and colleagues reported out of 76 critically ill patients with COVID-19, 23 patients had evidence of neurological involvement with $74 \%$ with encephalopathy and $7 \%$ with acute necrotizing encephalopathy 69 .

Acute Hemorrhagic Necrotizing Encephalopathy: Acute necrotizing encephalopathy is a rapidly progressive neurologic disorder that usually occurs subsequent to viral infections. ${ }^{70}$

A review by Poyiadji and colleagues reported a case of acute hemorrhagic necrotizing encephalopathy. The patient had CSF negative for bacterial and common viral infections with negative CSF SARS-CoV2 infection but RT-PCR was positive for Covid-19. Brain MRI showed presence of hyper intensity in bilateral temporal lobes and thalami. ${ }^{71}$

\section{CNS Infections/Meningitis/Meningoencephalitis:}

There are reports of encephalitis and meningitis in COVID-19. For example, the SARS-CoV-2 virus has been detected within the CSF of two patients with encephalitis 72,73 raising the likelihood of direct cerebral effects of the virus. Acute meningoencephalitis or meningitis is another complication of coronaviruses in infants and children. A 3-year-old with meningitis within the setting of $\mathrm{HCoV}-\mathrm{OC} 43$ serology could also be the primary case described within the literature; another case report of $\mathrm{HCoV}$ OC43 encephalitis in an 11-month-old boy with immunodeficiency was published 36 years later ${ }^{74,75}$. The sole series to this point describing features of coronavirus-associated encephalitis is from the Children's Hospital of Chenzhou in Hunan province ${ }^{56}$. Of 183 children under the age of 16 years admitted for acute encephalitis, 22(12\%) had coronavirus infection detected by IgM serology 76 . Eighty-two percent of those children were male, and also the mean age was 3 years. The course of the disease averaged 14.5 days, and everyone had a full recovery with no neurological sequelae.

Fever was present in $82 \%$, headache in $46 \%$, vomiting in $36 \%$, and seizure in $23 \%$. CSF pleocytosis was seen in $46 \%$, normal CSF glucose in $82 \%$, and elevated protein in $36 \%$. Compared to children hospitalized with pulmonary coronavirus, children with encephalitis had lower peripheral blood lymphocyte and eosinophil counts, higher neutrophil counts, and better serum 
levels of granulocyte-macrophage colony-stimulating factor (GMCSF). Children with encephalitis also had higher peripheral blood monocyte counts than healthy controls. When paired bio specimens were analyzed, levels of GM-CSF, IL-6, IL-8, and MCP-1 were higher within the CSF than within the serum of the encephalitic children 76 .

\section{Seizure disorders:}

Seizures associated with COVID-19 can occur as a sequel of encephalopathy or because of severe illness associated with non-epileptic seizures without brain injury or metabolic or multiple drug effects used to treat critical illness ${ }^{77}$. In either case seizures could be the initial presenting manifestation of COVID-19.

Seizures also can result in impairment of consciousness and are reported in other Corona viral infections. Additionally, subclinical seizures are reported in roughly $10 \%$ of patients with critical illness 78 , and patients with a primary seizure disorder are at higher risk of seizures and status epilepticus within the setting of severe infection ${ }^{79 .}$ Lu and colleagues 80 in an academic center reported a high proportion of breakthrough seizures in patients with epilepsy who have developed COVID-19. A recent report of 304 patients diagnosed with COVID-19 only documented two "seizure-like events" 50 with no confirmed cases of new-onset seizures. The study was limited by lack of clinical testing (e.g., electroencephalography, imaging) and the retrospective approach ${ }^{80}$. Case report of a patient with no history of epilepsy who had multiple apparent tonic-clonic seizures within the setting of COVID-19 may represent an unmasked seizure disorder or the direct effect of COVID-19 within the CNS, but further study in these cases are needed 81 .

\section{Movement Disorders:}

There are few reports of movement disorders in COVID19.Rabano Suarz P and his colleagues ${ }^{82}$ reported 3 patients with generalized myoclonus with both positive and negative jerks, predominantly involved facial, sternocleidomastoid, trapezius and upper extremity muscles. These myoclonus occurred spontaneously and were extremely sensitive to multisensory stimuli (auditive, tactile) or voluntary movements. After immunotherapy all 3 patients improved at least partially ${ }^{82}$.

\section{Parkinsonism / Parkinson's disease:}

Parkinson's disease is a common neurodegenerative disease that primarily aûects the basal ganglia system. Disruption of motor functions is one of its main clinical manifestations. Parkinson's disease is often preceded by anosmia which is a common feature of SARS-CoV2 infection ${ }^{83}$.Immune activation of the olfactory system might eventually lead to the misfolding of Alpha- synuclein and the development of Parkinson's disease 84 .This mechanism is supported by post mortem studies, showing increased levels of TNF, IL1, and IL6

85. CSF sero-positivity for several strains of coronaviruses has been reported in Parkinson's disease compared to age matched healthy controls ${ }^{86}$.

\section{Central Nervous System Demyelination:}

Demyelinating disorders were found to be associated with covid-19 could also affect the central nervous system. MRI imaging identified new demyelinating lesions in the periventricular white matter, bulbomedullary junction, cervical and dorsal spinal cord. 77

Delayed post hypoxic necrotizing leukoencephalopathy (DPHL) was also reported to be associated with COVID$19{ }^{86}$.MRI imaging result showed large areas of white matter demyelination with active remyelination and necrosis consistent with DPHL. 87

\section{Spinal cord involvement /Acute Myelitis:}

A case of acute myelitis in a 66 year old male patient with COVID-19 has been reported by Jhao and colleagues. He was SARS-CoV-2 positive with patchy changes in chest CT, developed weakness of both lower limbs with urinary and bowel incontinence, impaired sensations below level of thoracic-10. Upper limb examinations were normal. He had high level of inflammatory mediators such as CRP and IL- 6 which indicate an over reactive inflammatory response mediated by hyper activation of the immune system. ${ }^{88}$

A clinical case of acute transverse myelitis was reported from Wuhan, but an MRI and CSF finding weren't available ${ }^{88}$. The patient developed flaccid lowerextremity paralysis with loss of pinprick sensation and paresthesia below the thoracic-10 level and was successfully treated with steroids and intravenous immunoglobulin.

Post infectious etiology in terms of secondary immunogenic overreaction was proposed as the underlying mechanism in myelitis in COVID-19 75 .

\section{Guillain-Barré Syndrome and Peripheral Nerve Disorders:}

In the study by Mao et al., $8.9 \%$ of patients had peripheral nervous system manifestations 11 . The common manifestations include Guillain-Barré syndrome (GBS) and other related variants and loss of the sense of taste and smell. Reports of GBS in patients with COVID-19 are emerging. Currently, a complete of 27 reports on GBS and its variants in COVID-19 are reported. Pathogen-associated antibodies that attack peripheral nerves thanks to molecular mimicry are previously suggested as a disease mechanism in GBS. COVID-19-related GBS is especially seen within the elderly while typical GBS can 
occur in all told age groups ${ }^{89}$. None of the patients with post-COVID-19 GBS, tested positive for SARSCoV-2 within the CSF 90 points to an immune mechanism like inflammation secondary to a cytokine storm as a possible cause. A case series reported 5 cases of GBS in Italy after COVID-19 infection ${ }^{91}$. In 4 cases, patients presented with lowerextremity weakness and paresthesia. Patients developed symptoms a mean of 5 to 10 days after onset of viral symptoms. Electromyography studies showed 2 patients had AIDP and three had AMAN. Additional case reports describe a patient in Iran with AMAN 92 and a patient from Italy with Miller-Fisher-variant GBS ${ }^{93 .}$

Miller Fisher syndrome is characterized by the acute onset of external opthalmoplegia, ataxia, and loss of tendon reflexes. Some variants of GBS like Miller Fisher syndrome and polyneuritis cranialis are reported in two COVID-19 patients from Italy; both recovered fully within 2 weeks ${ }^{93}$.The pathogenesis of Miller Fisher syndrome and polyneuritis cranialis in SARS-CoV-2 infection may include immune mechanism or direct viral neuro-pathogenic effects 94.GBS with COVID-19 should be distinguished from critical illness neuropathy and myopathy, which appear later in the course of critical illness than GBS.

\section{Myasthenic Like Syndromes:}

While there are no current reports of de-novo cases of myasthenia caused by COVID-19, episodes of SARSCoV-2 related exacerbation of pre-existing myasthenia are recently reported 95,96 .

\section{Skeletal muscle injury and Rhabdomyolysis:}

Muscle weakness, fatigue or myalgia, and muscle atrophy are among the foremost commonly reported symptoms by patients with COVID-19 95, 97. For instance, the prevalence of myalgia among currently published reports may range from $21 \%$ to over $50 \%$ of affected patients. Moreover, myalgia tends to persist after cessation of viral shedding for a median time of 23 days ${ }^{98}$. Skeletal muscle injury was recorded in $10.7 \%$ of the COVID-19 patients studied by Mao et al. Creatine kinase (CK), D-dimer, serum globulin, and lactate dehydrogenase levels were found to be elevated in patients with muscle injury ${ }^{11}$. In another report, myalgia was noted in $34.8 \%$ of the studied COVID-19 patients 99. Consistently, some reports have described in patients with COVID-19 related myositis and rhabdomyolysis. These patients presented with elevated serum CK levels, yet as high serum levels of CRP, LDH, and ferritin. In addition to myositis and rhabdomyolysis, critical-illness myopathies, cachexia and sarcopenia have also been described in patients with COVID-19 95, 97.
Gefen and colleagues reported a case of 16 year old boy with covid19 and rhabdomyolysis. He presented with high fever, myalgia, and shortness of breath with dark colored urine. He had elevated liver enzymes with very high creatine kinase (CK-427656 U/L). Urine analysis revealed 11-25 $\mathrm{RBC} / \mathrm{HPF}$. With treatment patient improved and discharged at day 12 with creatine kinase level - 6526U/L. ${ }^{100}$

\section{COVID-19 associated psychiatric illness:}

Early reports from the continued COVID-19 pandemic suggest psychiatric morbidities that have some resemblance to those reported within the early phase of the SARS outbreak. Patients were reported to experience fear, loneliness, anger, and general distress, which, primarily attributed to the necessity for quarantine; and infection symptoms like fever and cough $^{101}$. Moreover, adverse eûects of treatments like insomnia from corticosteroids, and psychotic disorder from chloroquine, might exacerbate patients' mental status 101,102 77, 78. Additional reasons for psychiatric morbidities include experiencing adverse eûects of treatment during hospitalization, uncertainty regarding prognosis, and undergoing ICU care. Therefore, infection with SARS-CoV-2 is taken into account as a traumatic experience; this enhances anxiety and substantial mental distress. Within the immediate aftermath of the SARS epidemic, various psychiatric morbidity was reported. These included depression, adjustment reactions, anxiety, agitation, psychotic symptoms, delirium, and even higher suicidality 101, 103,104 . Within the early recovery phase, up to $35 \%$ of SARS survivors showed signs of tension, depression, or both 103, 105 . Importantly, post-traumatic stress reactions were identified in SARS survivors within the early, 2-4 week period, following discharge. Furthermore, about $45 \%$ of the respondents therein outbreaks were diagnosed with a minimum of one psychiatric disorder during the study period. Psychiatric disorders like major depression, posttraumatic stress disorder (PTSD), and adjustment disorder were described during the 6 months after patients' discharge 103, 104.

\section{COVID-19 associated neurological symptoms in pediatrics:}

Studies have shown that children experience mild form of COVID-19 disease; rare neurological complications have been reported. Cases of dystonic leg stiffness, abnormal gaze with altered responsiveness has been reported in a child with COVID-19 by Dugue and colleagues ${ }^{106}$.Another case with a child with COVID19 with encephalitis has been reported ${ }^{107}$.Neurological complications of COVID-19 seem to be higher in children with multi-system inflammatory syndrome (MIS-C). ${ }^{108}$ 
Review of 187 children with MIS-C from 6 studies showed a high incidence of neurological complications in MIS-C patients with COVID-19.Neurological manifestations includes headache, meningism and mental state alteration. Interestingly most patient achieve full recovery with IV-Immunoglobulin or steroid treatment. ${ }^{108}$ Recent international multicenter study analyzed neuro images of 38 children with COVID-19 related neurological complications and found that most common neuro imaging abnormality was para infectious immune mediated. Acute disseminated encephalomyelitis like changes were described in 16 patients, myelitis in 8 patients, neural enhancement in 13 patients, splenial lesions in 7 patients, and myositis in 4 patients Of which splenial lesions and myositis were predominant findings in patients with MIS-C. $18 \%$ of the patient presented with evidence of thromboembolic or vasculitic findings. ${ }^{109}$

\section{Long COVID-19 Syndrome/Post-acute COVID-19 Syndrome:}

Long COVID-19 syndrome or post-acute COVID-19 syndrome is a term that has been used to describe the complications that extend beyond the duration of initial illness and after recovery of SARS-CoV-2 infection. 110166

Recently these complications have becoming well recognized status and suggested as post infectious entity ${ }^{110}$.Post-acute COVID-19 syndrome has been defined by Ani Nalbandian and colleagues ${ }^{111}$ as persistence symptoms and/or delayed or long-term complications of SARS-CoV-2 complications beyond 4 weeks from the onset of the symptoms. (Fig.5).

Ani Nalbandian, Kartik Sehgal,Aakriti Gupta 'Mahesh V. Madhavan, et.al Nature Medicine, https://doi.org/ 10.1038/s41591-021-01283-Z

Based on recent literature it is further divided into two categories 1) Subacute or ongoing systematic COVID19, which includes symptoms and abnormalities present for 4-12 weeks beyond acute COVID-19 and 2) Chronic or post COVID-19 syndrome which include symptoms and abnormalities persisting or present beyond 12 week of the onset of the acute COVID-19 and not attributable to alternative diagnosis. 112, 113.

Early reports have now emerged on post-acute infectious consequences of COVID-19, with studies formed in United States, Europe, china reporting

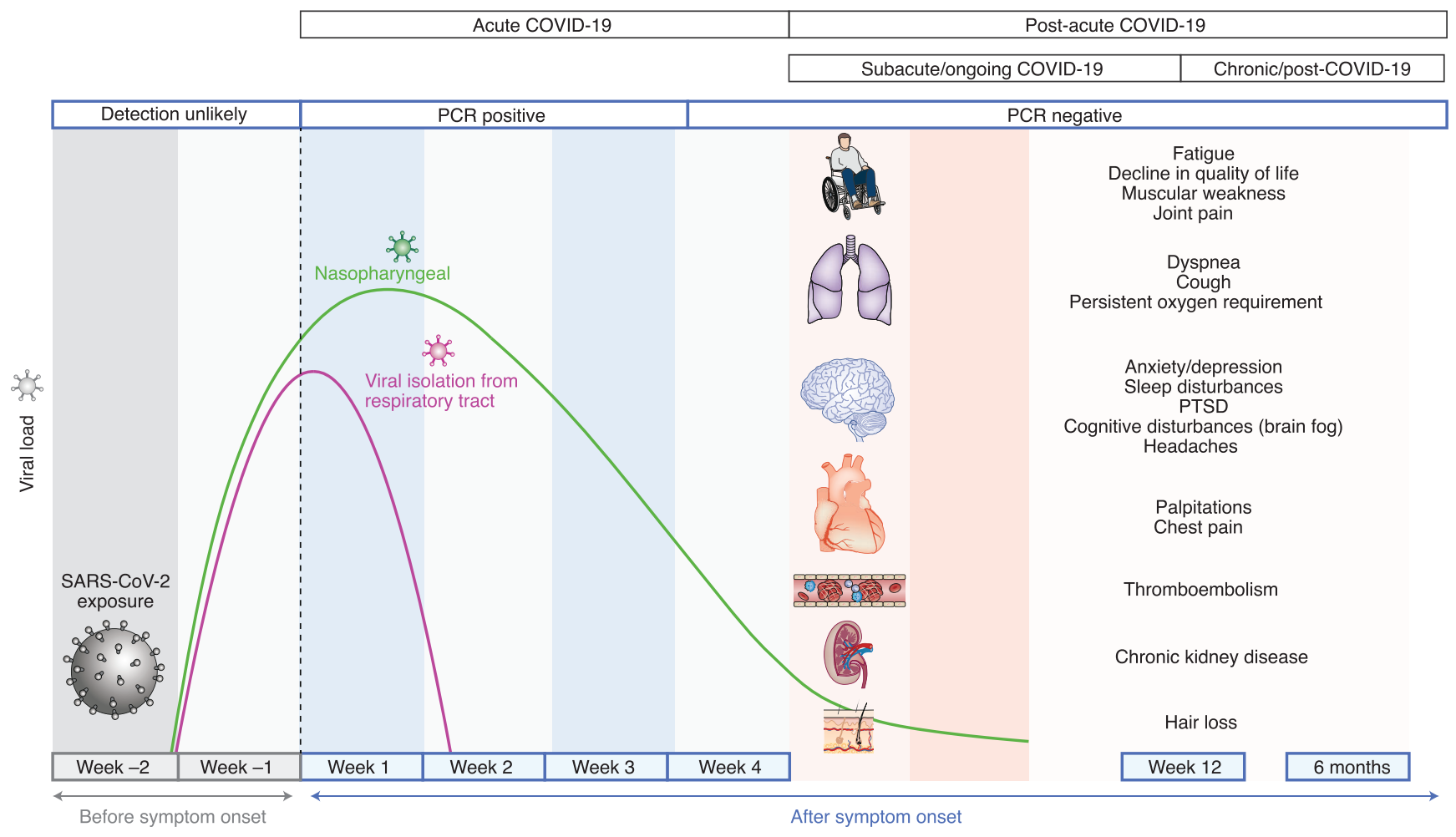

Fig.-5: Timeline of post-acute COVID-19. Acute COVID-19 usually lasts until 4 weeks from the onset of symptoms, beyond which replication-competent SARS-CoV-2 has not been isolated. Post-acute COVID-19 is defined as persistent symptoms and/or delayed or long-term complications beyond 4 weeks from the onset of symptoms. The common symptoms observed in post-acute COVID-19 are summarized. Post-acute COVID-19 syndrome. 
outcome for those who survive hospitalization for acute COVID-19.The findings from such studies include involvement of the pulmonary, hematologic, cardiovascular, renal, endocrine, gastrointestinal, hepatobiliary, dermatologic and multi system inflammatory syndrome (MIS-C) and neuropsychiatric. ${ }^{111}$ (Fig.-5)

These complications are mainly neurological symptoms which maybe a persistence of some symptoms or appearance of the new symptoms after the recovery 110. A report from the CDC indicated that $35 \%$ of the patients with mild COVID-19 did not return to baseline after recovery. ${ }^{114}$

Fatigue, changes in the concentration, loss of memory, foggy brain, sleep disorders, cough dyspnea were the main reported symptoms. ${ }^{166}$.Study by Tobacof and colleagues ${ }^{110}$ investigated post-acute COVID-19 symptoms that persist more than 6 weeks after the onset of acute symptoms found that most of the persistence symptoms along the patients were fatigue $(92 \%)$, loss of concentration or memory $(74 \%)$, weakness $(68 \%)$, headache (65\%), dizziness (64\%). ${ }^{110}$

Another study by Carfi and colleagues found that $87.4 \%$ of COVID-19 patients reported the persistence of at least one symptom, with fatigue being most common reported. The Quality of life was affected in $44.1 \%$ of the patient. ${ }^{115}$

The pathophysiology of neuropsychiatric complication in post-acute COVID-19 is mechanistically diverse and entails immune dysregulation, inflammation, microvascular thrombosis, iatrogenic effect of medication and psycho-social impact of infection ${ }^{170}$.A chronic low level brain inflammation along with the reduced ability to respond to new antigens and accumulation of memory T-cells may play a role in persistent effect of COVID-19. ${ }^{111}$

Other proposed mechanism include dysfunctional lymphatic drainage from the circumventricular organs. ${ }^{116}$

\section{Conclusions:}

This review summarizes the available information of the effects of SARS-CoV-2 on the nervous system, with an emphasis on the etio-pathogenesis and clinical features. The neurological symptoms are common in SARS-CoV-2 infection, although from the large number of cases reported from all over the world daily, the true prevalence, underlying mechanism (infectious, autoimmune, secondary to systemic complications), and outcomes of COVID-19 neurological manifestations still remain a key knowledge gap. Many global initiatives have emerged to address these critical questions. However the rapid and parallel implementation of these initiatives in a pandemic has resulted in some discrepant data elements and definitions of neurological symptoms and signs. These factors threaten the scientific rigor and need to be addressed by combined global efforts. Coronaviruses belong to a large family with extensive animal reservoirs and potential to make a leap to humans. This is unlikely to be the last pandemic humanity has faced and future pandemics caused by pathogens including viruses with higher infectivity and mortality may be even more severe. We are to gain an advantage in this battle with scientific knowledge and devotions to protect and optimize global health and prosperity.

\section{Acknowledgment}

To the front line workers especially health care professionals and the patients with their associates struggling this unwanted battle with courage and devotions.

\section{Source of Support}

No financial support was received for this article.

\section{Disclosure:}

The authors have no relevant disclosure and conflict of interest.

\section{Abbreviations:}

COVID-19 corona virus disease 19 , SARS-CoV-2 severe acute respiratory syndrome-corona virus 2 ; CNS central nervous system; PNS peripheral nervous system; CRP C-reactive protein;IL-6 interleukin-6 ; CK creatine kinase; PCR polymerase chain reaction; MRI magnetic resonance imaging; CT computed tomography; EEG electro encephalogram; BBB blood brain barrier; ICU intensive care unit; CSF cerebrospinal fluid; RNA ribonucleic acid; NMDAR N-methyl-D-aspartic acid receptor ;ACE-2 angiotensin converting enzyme 2;AIDP acute infective demyelinating polyneuropathy;AMAN acute motor axonal neuropathy ; HIV human immunodeficiency virus; RAS Renin angiotensin system; LDH lactic dehydrogenase

\section{References:}

1. Page J, Hinshaw D, McKay B (26 February 2021). "In Hunt for Covid-19 Origin, Patient Zero Points to Second Wuhan Market - The man with the first confirmed infection of the new coronavirus told the WHO team that his parents had shopped there". The Wall Street Journal. Retrieved 27 February 2021.

2. Zimmer C (26 February 2021). "The Secret Life of a Coronavirus - An oily, 100-nanometer-wide bubble of genes has killed more than two million people and reshaped the world. Scientists don't quite know what to make of it". Retrieved 28 February 2021. 
3. "Coronavirus disease (COVID-19): How is it transmitted?" World Health Organization (WHO). Retrieved 6 December 2020.

4. CDC (28 October 2020). "COVID-19 and Your Health". Centers for Disease Control and Prevention. Retrieved 21 April 2021.

5. “Transmission of COVID-19". European Centre for Disease Prevention and Control. Retrieved 6 December 2020.

6. Buitrago-Garcia D, Egli-Gany D, Counotte MJ, Hossmann S, Imeri H, Ipekci AM, et al. (September 2020). "Occurrence and transmission potential of asymptomatic and presymptomatic SARS-CoV-2 infections: A living systematic review and metaanalysis". PLOS Medicine. 17 (9): e1003346.https:// doi.org/10.1371/journal.pmed. 1003346 . PMid:32960881 PMCid:PMC7508369

7. Al-Tawfiq, J.A.; Leonardi, R.; Fasoli, G.; Rigamonti, D. Prevalence and Fatality Rates of COVID-19: What Are the Reasons for the Wide Variations Worldwide? Travel Med. Infect Dis. 2020, 35, 101711. https://doi.org/ 10.1016/j.tmaid.2020.101711. PMid:32360326 PMCid:PMC7188640.

8. Oran, D.P.; Topol, E.J. Prevalence of Asymptomatic SARS-CoV-2 Infection. Ann. Intern Med. 2020. https:/ /doi.org/10.7326/M20-3012. PMid:32491919 PMCid:PMC7281624

9. Zhang, J.; Dong, X.; Cao, Y.; Yuan, Y.; Yang, Y.; Yan, Y.; Akdis, C.A.; Gao, Y. Clinical Characteristics of 140 Patients Infected with SARS-CoV-2 in Wuhan, China. Allergy 2020, 75, 1730-1741. https://doi.org/10.1111/ all.14238. PMid:32077115

10. Cummings, M.J.; Baldwin, M.R.; Abrams, D.; Jacobson, S.D.; Meyer, B.J.; Balough, E.M.; Aaron, J.G.; Claassen, J.; Rabbani, L.E.; Hastie, J.; et al. Epidemiology, Clinical Course, and Outcomes of Critically Ill Adults with COVID-19 in New York City: A Prospective Cohort Study. Lancet 2020, 395, 1763-1770. https://doi.org/ 10.1016/S0140-6736(20)31189-2

11. Mao, L.; Jin, H.; Wang, M.; Hu, Y.; Chen, S.; He, Q.; Chang, J.; Hong, C.; Zhou, Y.; Wang, D.; et al. Neurologic Manifestations of Hospitalized Patients with Coronavirus Disease 2019 in Wuhan, China. JAMA Neurol. 2020, 77, 683-690. https://doi.org/10.1001/ jamaneurol.2020.1127. PMid:32275288 PMCid:PMC7 149362

12. Huang, C.; Wang, Y.; Li, X.; Ren, L.; Zhao, J.; Hu, Y.; Zhang, L.; Fan, G.; Xu, J.; Gu, X.; et al. Clinical Features of Patients Infected with 2019 Novel Coronavirus in Wuhan, China. Lancet 2020, 395, 497-506. https:// doi.org/10.1016/S0140-6736(20)30183-5

13. Clinical Questions about COVID-19: Questions and Answers Centers for Disease Control and Prevention COVID-19 Dashboard by the Center for Systems Science and Engineering (CSSE) at Johns Hopkins
University (JHU)". ArcGIS. Johns Hopkins University.

14. Helms J, Kremer S, Merdji H, et al. Neurologic features in severe SARS-CoV-2 infection. N Engl J Med 2020; 382: 2268-2270. https://doi.org/10.1056/ NEJMc2008597. PMid:32294339 PMCid:PMC7179967

15. Chen R, Wang K, Yu J, et al. The spatial and cell-type distribution of SARS-CoV-2 receptor ACE2 in human and mouse brain. bioRxiv. Epub ahead of print 9 April 2020. https://doi.org/10.1101/2020.04.07.030650

16. Desforges M, Le Coupanec A, Dubeau P, et al. Human coronaviruses and other respiratory viruses: underestimated opportunistic pathogens of the central nervous system? Viruses 2019; 12:14. https://doi.org/ 10.3390/v12010014. PMid:31861926 PMCid: PMC7020001

17. Gowrisankar YV, Clark MA. Angiotensin II regulation of angiotensin-converting enzymes in spontaneously hypertensive rat primary astrocyte cultures. J Neurochem 2016; 138: 74-85. https://doi.org/ 10.1111/jnc.13641. PMid:27085714

18. Desforges M,LeCoupanec A,Brison É,Meessen-Pinard M,Talbot PJ. Neuroinvasive and neurotropic human respiratory coronaviruses: potential neurovirulent agents in humans. Adv Exp MedBiol 2014;807: 7596. CrossRef PubMed Google Scholar. https:// doi.org/10.1007/978-81-322-1777-0_6. PMid:24619619 PMCid:PMC7121612

19. Swanson PA, McGavern DB. Viral diseases of the central nervous system. Curr Opin Virol 2015;11:44-54. https:/ / doi.org/ 10.1016 /j.coviro.2014.12.009. PMid:25681709 PMCid:PMC4456224

20. Netland J, Meyerholz DK, Moore S, et al. Severe acute respiratory syndrome coronavirus infection causes neuronal death in the absence of encephalitis in mice transgenic for human ACE2. J Virol 2008; 82: 72647275. https://doi.org/10.1128/JVI.00737-08. PMid:18495771 PMCid:PMC2493326

21. Li Y, Bai W, Hashikawa T. The neuroinvasive potential of SARS-CoV2 may play a role in the respiratory failure of COVID-19 patients. J Med Virol 2020; 92: 552-555. https://doi.org/10.1002/jmv.25728. PMCid:PMC7228344

22. Clark IA, Vissel B. The meteorology of cytokine storms, and the clinical usefulness of this knowledge. Semin Immunopathol. (2017) 39:505-16. https://doi.org/ 10.1007/s00281-017-0628-y. PMid:28451786 PMCid:PMC5495849

23. Mishra R, Singh SK. HIV-1 Tat C modulates expression of miRNA-101 to suppress VE-cadherin in human brain microvascular endothelial cells. J Neurosci. (2013) 33:5992-6000. https://doi.org/10.1523/ JNEUROSCI.4796-12.2013. PMid:23554480 PMCid:PMC6618916

24. Marta Bodro, Yaroslau Compta, Raquel Sánchez-Valle. Presentations and mechanisms of CNS disorders related 
to COVID-19. Neuroimmunology and neuroinflammation . DOI: https://doi.org/10.1212/ NXI.000000000000092

25. Gordon SM, Jackson JC, Ely EW, Burger C, Hopkins RO. Clinical identification of cognitive impairment in ICU survivors: insights for intensivists. Intensive Care Med 2004;30:1997-2008 . https://doi.org/10.1007/ s00134-004-2418-y. PMid:15549252 PMCid:PMC 7094980

26. Jain R.; Young, M.; Dogra, S.; Kennedy, H.; Nguyen, V.; Jones, S.; Bilaloglu, S.; Hochman, K.; Raz, E.; Galetta, S.; et al. COVID-19 Related Neuroimaging Findings: A Signal of Thromboembolic Complications and a Strong Prognostic Marker of Poor Patient Outcome. J. Neurol. Sci. 2020, 414. https://doi.org/ 10.1016/j.jns.2020.116923. PMid:32447193 PMCid: PMC7236667

27. Maryam Sharifian-Dorche, Philippe Huot, Michael Osherov, Dingke Wen, Alexander Saveriano, Paul S Giacomini, Jack P Antel, Ashkan Mowla . Neurological complications of coronavirus infection; a comparative review and lessons learned during the COVID-19 pandemic, https://doi.org/10.1016/j.jns.2020. 117085. PMid:32871412 PMCid:PMC7 413162

28. Fu L, Wang B, Yuan T, Chen X, Ao Y, Fitzpatrick T, et al. Clinical characteristics of coronavirus disease 2019 (COVID-19) in China: A systematic review and metaanalysis. J Infect 2020; 80:656-65. https://doi.org/ 10.1016/j.jinf.2020.03.041. PMid:32283155 PMCid:PMC7151416

29. Cao Y, Liu X, Xiong L, Cai K. Imaging and clinical features of patients with 2019 novel coronavirus SARSCoV-2: A systematic review and meta-analysis. J Med Virol 2020. https://doi.org/10.1002/jmv.25822. PMid:32242947 PMCid:PMC 7228215

30. Toscano G, Palmerini F, Ravaglia S, et al. Guillain-Barré syndrome associated with SARS-CoV-2. N Engl J Med. 2020. https://doi.org/10.1056/NEJMc2009191. PMid:32302082 PMCid:PMC7182017

31. Guan W, Ni Z, Hu Y, Liang W, Ou C, He J. Clinical characteristics of coronavirus disease 2019 in China. N Engl J Med 2020;382(18):1708-20. https://doi.org/ 10.1056/NEJMoa2002032. PMid:32109013 PMCid:PMC7092819

32. Belvis R. Headaches during COVID-19: My clinical case and review of the literature. Headache 2020. https:// doi.org/10.1111/head.13841. PMid:32413158 PMCid:PMC7273035

33. Bolay H., Gül A., Baykan B. COVID-19 is a Real Headache! Headache. 2020 May. https://doi.org/ 10.1111/head.13856. PMid:32412101 PMCid: PMC7272895

34. Hosseini AA, Shetty AK, Sprigg N, Auer DP,
Constantinescu CS. Delirium as a presenting feature in COVID-19: neuroinvasive infec- tion or autoimmune encephalopathy?. Brain Behav Immun. 2020;88: 6870. https://doi.org/10.1016/j.bbi.2020.06.012. PMid:32531427 PMCid:PMC7282789

35. AlkeridyWA,AlmaghlouthI,AlrashedR,etal. Aunique presentation of delirium in a patient with otherwise asymptomatic COVID-19. J AmGeriatrSoc.2020;68(7): 1382-1384. https://doi.org/10.1111/jgs. 16536. PMid:32383778 PMCid:PMC7272789

36. Beach SR, PraschanNC,Hogan C,etal. Deliriumin COVID-19:acase series and exploration of potential mechanisms for central nervous systeminvolvement. GenHospPsychiatry.2020;65:47-53. https://doi.org/ $10.1016 / \mathrm{j}$.genhosppsych.2020.05.008. PMid:32470824 PMCid:PMC7242189

37. Paniz-Mondolfi A, Bryce C, Grimes Z, et al. Central nervous system involvement by severe acute respiratory syndrome coronavirus-2 (SARS-CoV-2).JMedVirol. 2020; 92(7):699-702. https://doi.org/10.1002/ jmv.25915. PMid:32314810 PMCid:PMC7264598

38. Reichard RR, Kashani KB, Boire NA, Constantopoulos E, Guo Y, Lucchinetti CF. Neuropathology of COVID19: a spectrum of vascular and acute disseminated encephalomyelitis (ADEM)-like pathology. Acta Neuropathol.2020;140(1):1-6. https://doi.org/ 10.1007/s00401-020-02166-2. PMid:32449057 PMCid:PMC7245994

39. Kremer S, Lersy F, de Sèze J, et al. Brain MRI findings in severe COVID 19: A Retrospective Observational Study. Radiology.2020;297 (2):e242-e251. Epub 2020 Jun 16. https://doi.org/10.1148/radiol.2020202222. PMid:32544034 PMCid:PMC7301613

40. Sungnak, W, Huang, N, Bécavin, C, et al. SARS-CoV-2 entry factors are highly expressed in nasal epithelial cells together with innate immune genes. Nat Med 2020; 26: 681-687. https://doi.org/10.1038/s41591-0200868-6. PMid:32327758

41. Brann DH, Tsukahara T, Weinreb C, et al. Non-neural expression of SARS-CoV-2 entry genes in the olfactory epithelium suggests mechanisms underlying anosmia in COVID-19 patients. bioRxiv. Epub ahead of print 28 March 2020. https://doi.org/10.1101/2020.03.25. 009084

42. Fodoulian L, Tuberosa J, Rossier D, et al. SARS-CoV-2 receptor and entry genes are expressed by sustentacular cells in the human olfactory neuroepithelium. bioRxiv. Epub ahead of print 2 April 2020. https://doi.org/10.1101/2020.03.31.013268

43. Gutiérrez-Ortiz C, Méndez A, Rodrigo-Rey S, et al. Miller Fisher Syndrome and polyneuritis cranialis in COVID19. Neurology 2020; 95: e601. https://doi.org/ 10.1212/WNL.0000000000009619. PMid:32303650

44. Lechien JR, Chiesa-Estomba CM, De Siati DR, et al. Olfactory and gustatory dysfunctions as a clinical presentation of mild-to-moderate forms of the 
coronavirus disease (COVID-19): a multicenter European study. Eur Arch Otorhinolaryngol. 2020;111.

45. Vaira LA, Salzano G, Deiana G, De Riu G. Anosmia and ageusia: common findings in COVID-19 patients. Laryngoscope. 2020. https://doi.org/10.1002/ lary.28692. PMid:32237238 PMCid:PMC7228304

46. Wang, L.; Shen, Y.; Li, M.; Chuang, H.; Ye, Y.; Zhao, H.; Wang, H. Clinical Manifestations and Evidence of Neurological Involvement in 2019 Novel Coronavirus SARS-CoV-2: A Systematic Review and Meta-Analysis. J. Neurol. 2020, 1-13. https://doi.org/10.1007/ s00415-020-09974-2. PMid:32529575 PMCid:PMC 7288253

47. Lechien, J.R.; Chiesa-Estomba, C.M.; Place, S.; Laethem, Y.V.; Cabaraux, P.; Mat, Q.; Huet, K.; Plzak, J.; Horoi, M.; Hans, S.; et al. Clinical and Epidemiological Characteristics of 1420 European Patients with Mild-to-Moderate Coronavirus Disease 2019. J. Intern. Med. 2020, 288, 335-344.

48. Silvestro M, Tessitore A, Tedeschi G, Russo A. Migraine in the time of COVID-19. Headache 2020; 60:988-9. https://doi.org/10.1111/head.13803. PMid:32267962 PMCid:PMC7262112

49. Becker RC. COVID-19 update: Covid-19-associated coagulopathy. J Thromb Thrombolysis 2020; 50: 5467. https://doi.org/10.1007/s1 1239-020-02134-3. PMid:32415579 PMCid:PMC7225095

50. Li Y, Wang M, Zhou Y, Chang J, Xian Y, Mao L, et al. Acute cerebrovascular disease following COVID-19: A single center, retrospective, observational study. SSRN Electron J 2020. doi: 10.2139/ssrn. 3550025. https:/ /doi.org/10.2139/ssrn.3550025

51. Beyrouti R, Adams ME, Benjamin L, Cohen H, Farmer $\mathrm{SF}$, Goh YY, et al. Characteristics of ischaemic stroke associated with COVID-19. J Neurol Neurosurg Psychiatry 2020:jnnp-2020-323586. https://doi.org/ 10.1136/jnnp-2020-323586. PMid:32354768 PMCid: PMC7231545

52. Manousakis G, Jensen MB, Chacon MR, Sattin JA, Levine RL. The interface between stroke and infectious disease: infectious diseases leading to stroke and infections complicating stroke. Curr Neurol Neurosci Rep.2009;9(1):28-34.https://doi.org/10.1007/ s11910-009-0005-x PMid:19080750

53. Starke RM, Chalouhi N, Ali MS, etal. The role of oxidative stress in cerebral aneurysm formation and rupture. Curr Neuro vasc Res. 2013;10(3):247-255. https:// doi.org/10.2174/15672026113109990003. PMid: 23713738 PMCid:PMC3845363

54. Yaghi S, Ishida K, Torres J, et al. SARS2-CoV-2 and stroke in a New York Healthcare System. Stroke. Epub ahead of print 20 May 2020. https://doi.org/10.1161/ STROKEAHA.120.030335.PMid:32432996 PMCid:PMC 7258764
55. Tan Y-K, Goh C, Leow AST, et al. COVID-19 and ischemic stroke: a systematic review and metasummary of the literature. J Thromb Thrombolysis. Epub ahead of print 13 July 2020. https://doi.org/10. 1007/s 1 1239-020-02228-y. PMid:32661757 PMCid: PMC7358286

56. Oxley TJ, Mocco J, Majidi S, Kellner CP, Shoirah H, Singh IP, et al. Large-vessel stroke as a presenting feature of Covid-19 in the young. N Engl J Med 2020; 382:e60. https://doi.org/10.1056/NEJMc2009787. PMid:32343504 PMCid:PMC7207073

57. Zhao J, Gao HY, Feng ZY, Wu QJ. A Retrospective Analysis of the Clinical and Epidemiological Characteristics of COVID-19 Patients in Henan Provincial People's Hospital, Zhengzhou, China. Front Med (Lausanne). 2020;7:286. Published 2020 Jun 5. https://doi.org/10.3389/fmed.2020.00286. PMid: 32582740 PMCid:PMC7291880

58. Ntaios, G.; Michel, P.; Georgiopoulos, G.; Guo, Y.; Li, W.; Xiong, J.; Ostos, F.; Goyal, P.; González-Ortega, G.; Fuentes, P.; et al. Characteristics and Outcomes in Patients with COVID-19 and Acute Ischemic Stroke. Stroke 2020, 51, 254-258.

59. Oxley TJ, Mocco J, Majidi S, Kellner CP, Shoirah H, Singh IP, et al. Large-vessel stroke as a presenting feature of Covid-19 in the young. N Engl J Med 2020;382:e60. https://doi.org/10.1056/NEJMc 2009787. PMid:32343504 PMCid:PMC7207073

60. Singo Kihira, Javin Schfflein,Keon Mohmoudi, et.al , Association Of Corona Virus Disease ( Covid-19) with large vessel occlusion strokes: A Case Control Study,; AJR:216 January 2021, 216;150-156. https:/ / doi.org/ 10.2214/AJR.20.23847. PMid:32755225

61. Craen, A.; Logan, G.; Ganti, L. Novel Coronavirus Disease 2019 and Subarachnoid Hemorrhage: A Case Report. Cureus 2020, 12. https://doi.org/10.7759/ cureus.7846. PMid:32483497 PMCid:PMC7253081

62. Mutlu, N.; Berry, R.G.; Alpers, B.J. Massive Cerebral Hemorrhage: Clinical and Pathological Correlations. Arch. Neurol. 1963, 8, 644-661. https://doi.org/ 10.1001 / archneur. 1963.00460060074008 . PMid:14065777

63. Bao, Y.; Lin, S.Y.; Cheng, Z.H.; Xia, J.; Sun, Y.P.; Zhao, Q.; Liu, G.J. Clinical Features of COVID-19 in a Young Man with Massive Cerebral Hemorrhage. Case Rep. SN Compr. Clin. Med. 2020, 2, 703-709. https://doi.org/ 10.1007/s42399-020-00315-y. PMid:32838132 PMCid:PMC7245167

64. Romero-Sánchez C.M., Díaz-Maroto I., Fernández-Díaz E., Sánchez-Larsen Á., Layos-Romero A., García-García J. Neurologic Manifestations in Hospitalized Patients With COVID-19: The ALBACOVID Registry. Neurology. 2020 Jun 1. https://doi.org/10.1212/WNL.0000000 000009937. PMid:32482845

65. Sharifi-Razavi A., Karimi N., Rouhani N. COVID 19, and intracerebral hemorrhage: causative or coincidental. 
New Microbes New Infect. 2020 Mar;27. https:// doi.org/10.1016/j.nmni.2020.100669. PMid:32322398 PMCid:PMC7163302

66. Speeckaert M.M., Speeckaert R., Delanghe J.R. Potential underlying mechanisms of cerebral venous thrombosis associated with COVID-19. J Neuroradiol. 2020 Jun 26. S0150-9861(20)30206-6. https:// doi.org/ $10.1016 /$ j.neurad.2020.06.009. PMid:32620231 PMCid: PMC7319640

67. Kaplan, P.W.; Rossetti, A.O. EEG Patterns and Imaging Correlations in Encephalopathy: Encephalopathy Part II. J. Clin. Neurophysiol. 2011, 28, 233-251. https:// doi.org/ 10.1097 / WNP.0b013e31821c33a0. PMid:21633250

68. Mizuguchi, M.; Yamanouchi, H.; Ichiyama, T.; Shiomi, M. Acute Encephalopathy Associated with Influenza and Other Viral Infections. Acta Neurol. Scand. 2007, 115, 45-56. https://doi.org/10.1111/j.1600-0404.2007. 00809.x PMid:17362276

69. Scullen, T.; Keen, J.; Mathkour, M.; Dumont, A.S.; Kahn, L. Coronavirus 2019 (COVID-19)-Associated Encephalopathies and Cerebrovascular Disease: The New Orleans Experience. World Neurosurg. 2020. https://doi.org/10.1016/j.wneu.2020.05.192. PMid:32474092 PMCid:PMC7255727

70. Wu, X.; Wu, W.; Pan, W.; Wu, L.; Liu, K.; Zhang, H.-L. Acute Necrotizing Encephalopathy: An Underrecognized Clinicoradiologic Disorder. Mediat. Inflamm. 2015. https://doi.org/10.1155/2015/792578. PMid:25873770 PMCid:PMC4385702

71. Poyiadji, N.; Shahin, G.; Noujaim, D.; Stone, M.; Patel, S.; Griffith, B. COVID-19-Associated Acute Hemorrhagic Necrotizing Encephalopathy: Imaging Features. Radiology 2020, 296, 119-120. https://doi.org/ 10.1148/radiol.2020201187. PMid:32228363 PMCid:PMC7233386

72. Huang YH, Jiang D, Huang JT. SARS-CoV-2 detected in cerebrospinal fluid by PCR in a case of COVID-19 encephalitis. Brain Behav Immun 2020; 87: 149. https://doi.org/10.1016/j.bbi.2020.05.012. PMid:32387508 PMCid:PMC7202824

73. McAbee GN, Brosgol Y, Pavlakis S, et al. Encephalitis associated with COVID-19 infection in an 11-year-old child. Pediatr Neurol 2020; 109: 94. https://doi.org/ 10.1016/j.pediatrneurol. 2020.04.013 PMid:32586676 PMCid:PMC7180343.

74. Riski H, Hovi T (1980) Coronavirus infections of man associated with diseases other than the common cold. J Med Virol 6:259-265. https://doi.org/10.1002/ jmv.1890060309. PMid:6262459 PMCid:PMC7166474

75. Morfopoulou S,Brown JR, Davies EG, Anderson G,Virasami A, Qasim W, Chong WK, Hubank M, Plagnol V, Desforges M, Jacques TS, Talbot PJ, Breuer J Human coronavirus OC43 associated with fatal encephalitis. N Engl J Med 2016; 375(5):497-498. https://doi.org/

\subsection{6/NEJMc1509458. PMid:27518687}

76. Moriguchi T, Harii N, Goto J, et al. A first case of meningitis/encephalitis associated with SARSCoronavirus-2. Int J Infect Dis. 2020;94:55-8. https:/ /doi.org/10.1016/j.ijid.2020.03.062. PMid:32251791 PMCid:PMC7195378

77. Hepburn, M.; Mullaguri, N.; George, P.; Hantus, S.; Punia, V.; Bhimraj, A.; Newey, C.R. Acute Symptomatic Seizures in Critically Ill Patients with COVID-19: Is There an Association? Neurocrit Care 2020. https:// doi.org/10.1007/s12028-020-01006-1. PMid:3246 2412 PMCid:PMC7253233.

78. Lau SK, Woo PC, Yip CC, et al. Corona virus HKU1 and other corona virus infections in Hong Kong.JClin Microbiol. 2006; 44(6):2063-2071. https://doi.org/ 10.1128/JCM.02614-05. PMid:16757599 PMCid: PMC1489438

79. Li Y, Li H, FanR, et al. Corona virus infections in the central nervous system and respiratory tract show distinct features in hospitalized children. Intervirology. 2016;59(3):163-169.https://doi.org/10.1159/ 000453066. PMid:28103598 PMCid:PMC 7179523

80. Lu L, Xiong W, Liu D, et al. New onset acute symptomatic seizure and risk factors in corona virus disease 2019:a retrospective multicenter study. Epilepsia. Published online April18, 2020. https:// doi.org/10.1111/epi.16524. PMCid:PMC7264627

81. Karimi N, Sharifi Razavi A, Rouhani N. Frequent convulsive seizures in an adult patient with COVID19:acasereport.Iran Red Crescent Med J. 2020;22(3):e102828. https://doi.org/10.5812/ircmj

82. Rábano-Suárez P., Bermejo-Guerrero L., MéndezGuerrero A., Parra-Serrano J., Toledo-Alfocea D., Sánchez-Tejerina D. Generalized myoclonus in COVID19. Neurology. 2020 May 21. https://doi.org/10.1212/ WNL.0000000000009829. PMid:32439821

83. Vaira LA, Salzano G,Deiana G.De Riu G. Anosmia and Ageusia: Common Findings In Covid-19 Patients. Laryngoscopy 2020;130:1787. https://doi.org/ 10.1002/lary.28692. PMid:32603478 PMCid:PMC 7361620

84. Blum-Degen D, Muller T,Kuhn W, et.al, Interleukin-1 beta and Interleukin- 6 are elevated in the cerebrospinal fluid of Alzheimer's and denovo Parkinson's disease patients. NeuroSci lett1995;202:17-20. https:// doi.org/10.1016/0304-3940(95)12192-7

85. Lema Tone CM, Tyson $\mathrm{T}$, Rey NL, et.al,. Inflammation and alpha-synuclein's prion -like behavior in Parkinsons Disease- Is there a link? MolNeuroBiol 2013; 47:561-74. https://doi.org/10.1007/s12035012-8267-8. PMid:22544647 PMCid:PMC3589652

86. Fazzini E, Fleming J, Fahn S. Cerebrospinal ûuid antibodies to coronavirus in patients with Parkinson's disease. Movement Disord. (1992) 7:153- 8. https:// doi.org/10.1002/mds.870070210. PMid:1316552 PMCid:PMC7168426 
87. Radmanesh, A.; Derman, A.; Ishida, K. COVID-19Associated Delayed Posthypoxic Necrotizing Leukoencephalopathy. J. Neurol. Sci. 2020, 415, 116945. https://doi.org/10.1016/j.jns.2020.116945. PMid:32480073 PMCid:PMC7251359

88. Zhao K, Huang J, Dai D, Feng Y, Liu L, Nie S. Acute myelitis after SARS-CoV-2 infection: a case report. Published March 18, 2020. Accessed May 19, 2020. https://doi.org/10.1101/2020.03.16.20035105

89. Gupta A, Paliwal VK, Garg RK. Is COVID-19-related Guillain-Barré syndrome different? Brain Behav Immun 2020; 87: 177-178. https://doi.org/10.1016/ j.bbi.2020.05.051. PMid:32445789 PMCid:PMC7 239011

90. Finsterer J, Scorza FA, Ghosh R. COVID-19 polyradiculitis in 24 patients without SARS-CoV-2 in the cerebro-spinal fluid. J Med Virol. Epub ahead of print 4 June 2020. https://doi.org/10.1002/ jmv.26121. PMid:32497288 PMCid:PMC7300798

91. Toscano G, Palmerini F, Ravaglia S, et al. Guillain-Barré syndrome associated with SARS-CoV-2. N Engl J Med. 2020. https://doi.org/10.1056/NEJMc2009191 PMid:32302082 PMCid:PMC7182017

92. Sedaghat Z, Karimi N. Guillain Barre Syndrome associated with COVID-19 infection: a case report. J Clin Neurosci. 2020; S0967-5868(20)30882-1.

93. Gutiérrez-Ortiz C, Méndez A, Rodrigo-Rey S, et al. Miller Fisher Syndrome and polyneuritis cranialis in COVID19. Neurology 2020; 95: e601. https://doi.org/ 10.1212/WNL.0000000000009619. PMid:32303650

94. Edward J Needham, Sherry H-Y Chou, Alasdair J Coles , David K Menon Neurological Implications of COVID19 Infection, https://doi.org/10.1007/s12028-02000978-4. PMid:32346843 PMCid:PMC7188454

95. Paliwal VK, Garg RK, Gupta A, et al. Neuromuscular presentations in patients with COVID-19. Neurol Sci 2020:1-18. https://doi.org/10.1007/s10072-02004708-8. PMid:32935156 PMCid:PMC7491599

96. Anand P, Slama MCC, Kaku M, et al. COVID-19 in patients with myasthenia gravis. Muscle Nerve 2020; 62:254-8. https://doi.org/10.1002/mus. 26918. PMid:32392389 PMCid:PMC7272991.

97. Guidon AC, Amato AA. COVID-19 and neuromuscular disorders. Neurology 2020;94(22):959-69. https:// doi.org/ 10.1212 / WNL.0000000000009566. PMid:32284362.

98. Corsini Campioli C, Cano Cevallos E, et al. Clinical predictors and timing of cessation of viral RNA shedding in patients with COVID-19. J Clin Virol 2020;130:104577 https://doi.org/10.1016/j.jcv.2020. 10457 10.1016/j.jcv.2020.10457. https://doi.org/ 10.1016/j.jcv.2020.104577. PMid:32777762 PMCid: PMC7405830

99. Wang D, Hu B, Hu C, et al. Clinical characteristics of 138 hospitalized patients with 2019 novel coronavirusinfected pneumonia in Wuhan, China. J Am Med Assoc
2020; 323: 1061-1069. https://doi.org/10.1001/ jama.2020.1585. PMid:32031570 PMCid:PMC7042881

100. Gefen, A.M.; Palumbo, N.; Nathan, S.K.; Singer, P.S.; Castellanos-Reyes, L.J.; Sethna, C.B. Pediatric COVID19-Associated Rhabdomyolysis: A Case Report. Pediatr. Nephrol. 2020, 35, 1517-1520. https://doi.org/ 10.1007/s00467-020-04617-0. PMid:32447505 PMCid:PMC7244938

101. de Medeiros Carvalho PM, Moreira MM, de Oliveira MN, Landim JM, Neto ML.The psychiatric impact ofthenovelcoronavirus outbreak. Psychiatry Res. (2020) 286:112902. https://doi.org/10.1016/j.psychres. 2020.112902. PMid:32146248 PMCid:PMC7133679

102. Telgt DS, van der Ven AJ, Schimmer B, DroogleeverFortuyn HA, Sauerwein RW. Serious psychiatric symptoms after chloroquine treatment following experimental malaria infection. Ann Pharmacother. (2005) 39:551- 4. doi: 10.1345/aph.1E409 84. Davydow DS, Desai SV, Needham. https://doi.org/ 10.1345/aph.1E409. PMid:15728331

103. Davydow DS, Desai SV, Needham DM, Bienvenu OJ. Psychiatric morbidity in survivors of the acute respiratory distress syndrome: a systematic review. Psychosomatic Med. (2008) 70:512-9. https://doi.org/ 10.1097/PSY.0b013e31816aa0dd. PMid:18434495.

104. Wu P, Fang Y, Guan Z, Fan B, Kong J, Yao Z, et al. The psychological impact of the SARS epidemic on hospital employees in China: exposure, risk perception, and altruistic acceptance of risk. Canad J Psychiatry. (2009) 54:302-11. https://doi.org/10.1177/07067437090 5400504. PMid:19497162 PMCid:PMC3780353

105. Mak IW, Chu CM, Pan PC, Yiu MG, Chan VL. Long-term psychiatric morbidities among SARS survivors. General Hospital psychiatry. (2009) 31:318-26. https://doi.org/ 10.1016/j.genhosppsych.2009.03.001.PMid: 19555791 PMCid:PMC7112501

106. Dugue, R.; Cay-Martínez, K.C.; Thakur, K.T.; Garcia, J.A.; Chauhan, L.V.; Williams, S.H.; Briese, T.; Jain, K.; Foca, M.; McBrian, D.K.; et al. Neurologic Manifestations in an Infant with COVID-19. Neurology 2020, 94, 1100. https://doi.org/10.1212/WNL. 0000000000009653. PMid:32327489 PMCid:PMC 7455334

107. McAbee, G.N.; Brosgol, Y.; Pavlakis, S.; Agha, R.; Gaffoor, M. Encephalitis Associated with COVID-19 Infection in an 11-Year-Old Child. Pediatric Neurol. 2020, 109, 94. https://doi.org/10.1016/j.pediatr neurol. 2020.04.013. PMid:32586676 PMCid:PMC 7180343

108. Chen, T.-H. Neurological Involvement Associated with COVID-19 Infection in Children. J. Neurol. Sci. 2020, 418. https://doi.org/10.1016/j.jns.2020.117096. PMid:32823135 PMCid:PMC7423535

109. Lindan, C.E.; Mankad, K.; Ram, D.; Kociolek, L.K.; Silvera, V.M.; Boddaert, N.; Stivaros, S.M.; Palasis, S.; 
Akhtar, S.; Alden, D.; et al. Neuroimaging Manifestations in Children with SARS-CoV-2 Infection: A Multinational, Multicentre Collaborative Study. Lancet Child. Adolesc. Health 2021, 5, 167-177. https:/ /doi.org/10.1016/S2352-4642(20)30362-X

110. Tabacof, L.; Tosto-Mancuso, J.; Wood, J.; Cortes, M.; Kontorovich, A.; McCarthy, D.; Rizk, D.; Mohammadi, N.; Breyman, E.; Nasr, L.; et al. Post-Acute COVID-19 Syndrome Negatively Impacts Health and Wellbeing despite Less Severe Acute Infection. medRxiv 2020, 20226126. https://doi.org/10.1101/2020.11.04. 20226126

111. Ani Nalbandian, Kartik Sehgal,Aakriti Gupta ,Mahesh V. Madhavan et.al. post-acuteCOVID19 syndrome. Nature Medicine, https://doi.org/10.1038/s41591021-01283-z PMid:33753937

112. Greenhalgh, T., Knight, M., A'Court, C., Buxton, M. \& Husain, L. Management of post-acute COVID-19 in primary care. Brit. Med. J. 370, m3026 (2020). https:/ /doi.org/10.1136/bmj.m3026. PMid:32784198
113. Shah, W., Hillman, T., Playford, E. D. \& Hishmeh, L. Managing the long term effects of COVID-19: summary of NICE, SIGN, and RCGP rapid guideline. Brit. Med. J. 372, n136 (2021). https:/ / doi.org/ 10.1136/bmj.n136. PMid:33483331

114. Tenforde, M.W. Symptom Duration and Risk Factors for Delayed Return to Usual Health Among Outpatients with COVID-19 in a Multistate Health Care Systems NetworkUnited States, March-June 2020. MMWR Morb. Mortal Wkly. Rep. 2020, 69.

115. Li,Y.;M.;Wang,M.;Zhou,Y.;Chang,J.;Xian,Y.;Wang,D.; Mao,L.;Jin,H.;Hu,B. Acute Cerebrovascular Disease following Covid-19: A Single Center, Retrospective, Observational study. Stroke Vasc. Neuol. 2020;5(3): 279-289. https://doi.org/ 10.1136/svn-2020-000431. PMCID: PMC7371480 . PMID: 32616524

116. Perrin, R. et al. Into the looking glass: post-viral syndrome post COVID-19. Med. Hypotheses 144, 110055 (2020). https://doi.org/10.1016/j.mehy. 2020.110055. PMid:32758891 PMCid:PMC7320866. 